\title{
SUHU PERMUKAAN LAUT PERAIRAN INDONESIA DAN HUBUNGANNYA DENGAN PEMANASAN GLOBAL
}

\author{
M. Djazim Syaifullah ${ }^{11}$ \\ 1)Peneliti UPT Hujan Buatan, Badan Pengkajian dan Penerapan Teknologi (BPPT) \\ Diterima tanggal: 20 Januari 2015; Diterima setelah perbaikan: 9 April 2015; Disetujui terbit tanggal 12 Juni 2015
}

\begin{abstract}
ABSTRAK
Analisis suhu permukaan laut/SPL (Sea Surface Temperature - SST) telah dilakukan di perairan Indonesia untuk melihat hubungannya dengan pemanasan global. Data yang digunakan adalah data suhu permukaan laut (sumber: National Centers for Environmental Prediction, National Weather Service, NOAA) dalam bentuk grid format ASCII selama 32 tahun (1982 2014), dengan skala spasial $1^{\circ} \times 1^{\circ}$ geografis dan skala temporal mingguan. Analisis dilakukan dengan dua cara yaitu analisis temporal dan spasial. Analisis temporal untuk melihat trend dari anomali suhu permukaan laut rerata beberapa wilayah tertentu, sedangkan analisis spasial untuk melihat wilayah yang mengalami kenaikan suhu permukaan laut dan sebaliknya. Hasil analisis menunjukkan bahwa selama lebih 32 tahun telah terjadi peningkatan suhu permukaan Lautan di wilayah Indonesia yang bervariasi. Kenaikan suhu permukaan laut (SPL) yang paling besar terjadi di Lautan Pasifik Barat di sebelah utara Papua. Secara umum dapat dilihat bahwa anomali SPL di wilayah Indonesia terbagi menjadi anomali positif dan negatif yang terpisah di belahan bumi bagian selatan dan belahan bumi bagian utara.
\end{abstract}

Kata kunci: Anomali suhu permukaan laut, perairan Indonesia, analisis spasial, pemanasan global

\section{ABSTRACT}

Analysis of the sea surface temperatures have been done in Indonesian waters to investigate its relation to the global warming. Data in the form of grid the format have 32 years long with scales spatial $1^{\circ} \times 1^{\circ}$ geographyc and temporal scale weekly is used. Analysis is conducted by two ways namely temporal and spatial analysis. The Temporal analysis is to see the trend of mean temperature anomaly of the seain some certain regions, while spatial analysis is to see which area experiencing a rise in sea surface temperature and which ones are otherwise. The result of analysis shows that in over 32 years there has been increasing sea surface temperature being varied. The highest increasing of sea surface temperature occurs in marine the western pacific to the North of Papua. In general it can be seen that the sea surface temperature anomaly in the Indonesia waters was divided into negative and positive anomaly separate in Southern hemisphere and the Northern hemisphere.

Keywords: Sea surface temperature anomaly, Indonesian waters, spacial analysis, global warming

\section{PENDAHULUAN}

Pemanasan Global atau Global Warming adalah suatu istilah yang menunjukkan pada peningkatan suhu rata-rata di atas permukaan bumi. Suhu udara rata-rata permukaan bumi meningkat sekitar $0,74^{\circ} \mathrm{C}$ dalam 100 tahun terakhir. Banyak ahli memperkirakan bahwa suhu rata-rata akan naik bertambah dari $1,4^{\circ} \mathrm{C}$ sampai dengan $5,8^{\circ} \mathrm{C}$ sampai tahun 2100 . Sedangkan Intergovernmental Panel on Climate Change (IPCC) memprediksi bahwa suhu global cenderung meningkat sebesar $1,1^{\circ} \mathrm{C}$ sampai $6,4^{\circ} \mathrm{C}$ dalam 90 tahun ke depan (IPCC dalam Masters, 2012).

Sumber energi utama dari semua kehidupan di bumi adalah matahari yang memancarkan radiasinya menembus lapisan atmosfer bumi dalam bentuk gelombang pendek. Radiasi tersebut akan dipantulkan kembali ke angkasa dalam bentuk gelombang panjang, sebagian gelombang tersebut diserap oleh gas rumah kaca, yaitu $\mathrm{CO}_{2}, \mathrm{CH}_{4}, \mathrm{~N}_{2} \mathrm{O}$, HFCs dan $\mathrm{SF}_{4}$ yang berada di atmosfer. Akibatnya gelombang panjang yang bersifat panas tersebut terperangkap di dalam atmosfer bumi. Peristiwa ini terjadi berulang - ulang, sehingga menyebabkan suhu rata-rata di permukaan bumi meningkat. Peristiwa inilah yang disebut dengan pemanasan global.

Rata-rata peningkatan suhu akan lebih cepat bila dibandingkan dengan waktu lampau. Para ilmuwan mencemaskan bahwa apakah masyarakat dunia dan ekosistem alam dapat beradaptasi dengan cepat terhadap perubahan iklim yang terjadi.

Beberapa aktivitas manusia yang ditengarai dapat menyebabkan pemanasan global misalnya perambahan yang mengakibatkan kerusakan hutan. Salah satu fungsi tumbuhan yaitu menyerap karbondioksida $\left(\mathrm{CO}_{2}\right)$, yang merupakan salah satu dari gas rumah kaca, dan mengubahnya menjadi oksigen $\left(\mathrm{O}_{2}\right)$. Kemudian, sampah menghasilkan gas metana $\left(\mathrm{CH}_{4}\right)$. Diperkirakan 1 ton sampah padat menghasilkan $50 \mathrm{~kg}$ gas metana (Sudarman, 2010). Dengan meningkatnya jumlah penduduk dunia, diperkirakan pada Tahun 2020 sampah yang dihasilkan mencapai 500 juta $\mathrm{kg} / \mathrm{hari}$ atau 190 ribu ton/tahun. Dengan jumlah ini maka sampah akan mengemisikan gas metana sebesar 9.500 ton/tahun. Sektor pertanian dan peternakan juga memberikan kontribusi terhadap peningkatan emisi gas rumah kaca melalui pemanfaatan pupuk serta praktek pertanian, pembakaran sisa-sisa tanaman, dan pembusukan 
sisa-sisa pertanian, serta pembusukan kotoran ternak. Dari sektor ini gas rumah kaca yang dihasilkan berupa gas metana $\left(\mathrm{CH}_{4}\right)$ dan gas dinitro oksida $\left(\mathrm{N}_{2} \mathrm{O}\right)$. Di Indonesia, sektor pertanian dan peternakan menyumbang emisi gas rumah kaca sebesar 8,05\% dari total gas rumah kaca yang diemisikan ke atmosfer

Dampak yang paling nyata dari pemanasan global sampai saat ini adalah perubahan iklim. Pemanasan global telah meningkatkan terjadinya kekeringan secara global, gelombang panas, dan frekuensi terjadinya badai tropis. Kenaikan suhu global akan menyebabkan mencairnya es di kutub utara dan selatan sehingga mengakibatkan terjadinya pemuaian massa air laut, dan kenaikan permukaan air laut. Pemanasan global juga akan menyebabkan pergeseran musim sebagai akibat dari adanya perubahan pola curah hujan. Perubahan iklim mengakibatkan intensitas hujan yang tinggi pada periode yang singkat serta musim kemarau yang panjang. Kedua peristiwa tersebut akan menimbulkan dampak pada beberapa sektor. Pada akhirnya perubahan iklim berakibat pada pergeseran musim dan perubahan pola curah hujan dan akan mempengaruhi ketahanan pangan nasional.

Beberapa tulisan mengenai suhu permukaan laut sudah banyak dilakukan diantaranya Aldrian et al. (2003), mengidentifikasi wilayah hujan yang dominan di Indonesia dan hubungannya dengan SPL. Awaluddin (2010) melakukan kajian perbedaan SPL di wilayah Indonesia. Emiyati et al. (2010) melakukan analisis multitemporal SPL dengan menggunakan teknik penginderaan jauh. Syaifullah (2010) melakukan penelitian SPL di selatan Jawa dan pengaruhnya terhadap curah hujan DAS Citarum.
Febriani et al. (2014) meneliti pengaruh SPL terhadap distribusi curah hujan di Sulawesi Utara. Tetapi analisis spasial secara luas mencakup seluruh perairan wilayah Indonesia dan secara temporal dalam waktu yang panjang belum banyak dilakukan terutama tren kenaikan/penurunan suhu permukaan laut. Tulisan ini bertujuan melihat seberapa besar kenaikan/ penurunan suhu permukaan laut (SPL) khususnya di perairan Indonesia dengan data pengamatan time series selama beberapa dekade ke belakang. Analisis pemanasan global dari SPL dilakukan secara temporal maupun spasial. Selain itu juga analisis spasial dilakukan dari nilai slope anomali SPL untuk melihat seberapa besar kenaikannya di perairan Indonesia dihubungkan dengan pemanasan global.

\section{METODE PENELITIAN}

\section{Lokasi Penelitian}

Lokasi penelitian seluruh perairan Indonesia meliputi Samudera Hindia, Laut Cina Selatan, Samudera Pasifik Bagian Barat dan lautan pedalaman. Secara geografis lokasi penelitian berada pada posisi $10^{\circ} \mathrm{LU}-15^{\circ} \mathrm{LS}$ dan $090^{\circ} \mathrm{BT}-150^{\circ} \mathrm{BT}$ (Gambar 1). Luas daerah penelitian $6.771 \times 2.886 \mathrm{~km}^{2}$. atau sekitar 19,54 juta $\mathrm{km}^{2}$. Analisis lebih detil difokuskan pada perairan yang lebih luas yaitu Samudera Hindia, Samudera Pasifik bagian barat dan Laut Cina Selatan, mengingat perubahan SPL untuk wilayah ini akan memberikan pengaruh yang besar bagi wilayah sekitarnya.

\section{Bahan}

Suhu Permukaan Laut (SPL) adalah suhu air

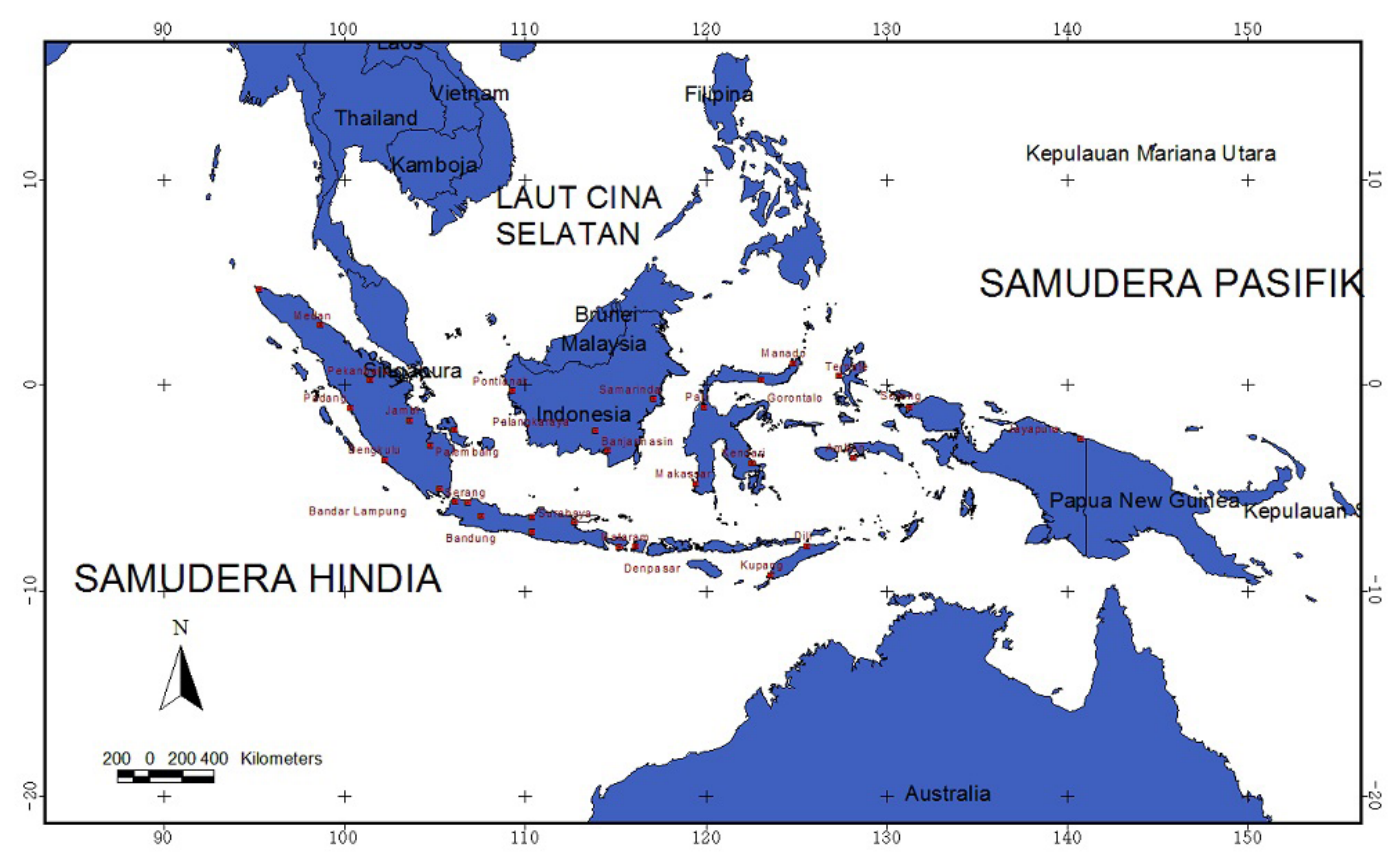

Gambar 1. Peta daerah penelitian yang mencakup seluruh perairan Indonesia. 
yang berada di permukaan laut diukur pada kedalaman $1 \mathrm{~mm}$ s.d $20 \mathrm{~m}$. Pengukuran dapat dilakukan dengan dua cara yaitu secara langsung menggunakan thermometer dan pengukuran tidak langsung menggunakan sensor satelit (citra satelit). Citra satelit diunduh dari situs : http://rda.ucar.edu/datasets/ ds277.0/ dalam bentuk grid format ASCII time series selama rentang 32 tahun (1982 - 2014) dengan skala spasial $1^{\circ} \times 1^{\circ}$ geografis dan skala temporal mingguan. Sebanyak 1.586 buah grid digunakan dalam penelitian ini (Tabel 1) yang mencakup seluruh perairan Indonesia.

Data SPL ini merupakan hasil analisis optimum interpolation Sea Surface Temperature (OISST) setiap minggunya. Analisis dilakukan terhadap pengamatan satelit in situ ditambah dengan simulasi SPL terhadap tutupan es. Sebelum analisis dihitung, data satelit disesuaikan terhadap bias dengan menggunakan metode Reynolds (Reynolds, 1988 \& Reynolds \& Marsico, 1993, serta Reynolds et al., 2002). Dalam penelitian ini digunakan versi 2 dengan nama filenya adalah : oisst.\{yyyymmdd\}, dimana \{yyyymmdd\} adalah tahun, bulan dan tanggal pertengahan minggu. Bentuk file terkompres dalam bentuk tar. File-file tersebut ditulis dalam standar biner IEEE (big-endian). Setiap file berisi empat record yang dapat dijelaskan sebagai berikut:

- $\quad$ record 1 : tanggal dan versi data / OIV2 (8 kata integer 4-byte).

- $\quad$ record 2 : nilai SST di setiap grid o geografi (360 x 180, 4 byte real words)

- $\quad$ record 3 : error varians yang ternormalisasi (360 x 180 , 4 byte real words)

- $\quad$ record 4 : es konsentrasi di setiap gridnya (360 × 180,1 byte integer words)

Tidak ada analisis terhadap permukaan tanah (daerah daratan). Nilai di permukaan tanah dikosongkan dengan interpolasi Cressman (Cressman, 1959) untuk menghasilkan grid menyeluruh terhadap masingmasing grid. Daerah lautan dan daratan ditentukan dengan sebuah land sea mask, yang isinya nilai numerik 1 untuk daerah lautan dan nilai numerik 0 untuk daerah daratan.
Program standar dalam bahasa Fortran disediakan untuk membaca format data tersebut dengan metode akses sekuensial (fortran sequential access). Secara teknis masing-masing record dalam file tersebut (yang berisi parameter) dipisahkan dengan data kontrol 4 byte di awal nilai parameter tersebut yang mengindikasikan jumlah byte dalam masingmasing record. Tabel 1 berikut memberi informasi spesifikasi data SPL yang digunakan dalam penelitian ini.

\section{Pengolahan Data}

Suhu permukaan laut diasosiasikan sebagai indeks banyaknya uap air pembentuk awan di atmosfer. Jika suhu permukaan laut panas maka uap air di atmosfer banyak akibat proses konveksi atau penguapan. Sebaliknya, jika suhu permukaan laut dingin maka uap air di atmosfer menjadi berkurang akibat kurangnya penguapan. Suhu permukaan laut di wilayah Indonesia mempunyai kisaran yang cukup lebar yaitu $26,0^{\circ} \mathrm{C}$ hingga $31,5^{\circ} \mathrm{C}$.

Untuk melihat pengaruh pemanasan global diamati dari anomali suhu permukaan laut. Anomali SPL didefinisikan sebagai penyimpangan suhu permukaan laut pada saat tertentu terhadap nilai normal/historisnya. Nilai normal dihitung dari rerata SPL dari data yang cukup panjang.

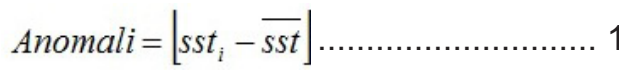

$$
\begin{aligned}
& \overline{s s t}=\frac{\sum_{i=1}^{n} s s t_{i}}{n}
\end{aligned}
$$

Untuk melakukan pemrosesan data yang sangat besar diperlukan beberapa tahapan (Gambar 2). Masing-masing tahapan pekerjaan dibuatkan suatu script pemrograman. Script dan program berguna membantu meringankan pekerjaan dalam mengunduh, mengolah dan memproses data sehingga analisis

Tabel 1.

Spesifikasi data SPL yang digunakan dalam penelitian ini

\begin{tabular}{ll}
\hline Parameter & Keterangan \\
\hline Jenis data & Sea Surface Temperature/SST/SPL \\
Sumber data & N O A A \\
Resolusi spasial & $1^{\circ}$ X $1^{\circ}$ Geographic \\
Resolusi temporal & Mingguan \\
Metode interpolasi & Optimum Interpolation \\
Jml grid bujur & 61 buah (90BT 150BT) \\
Jml grid lintang & 26 buah (15LS 10LU) \\
Total jumlah grid & 1.586 buah \\
\hline
\end{tabular}




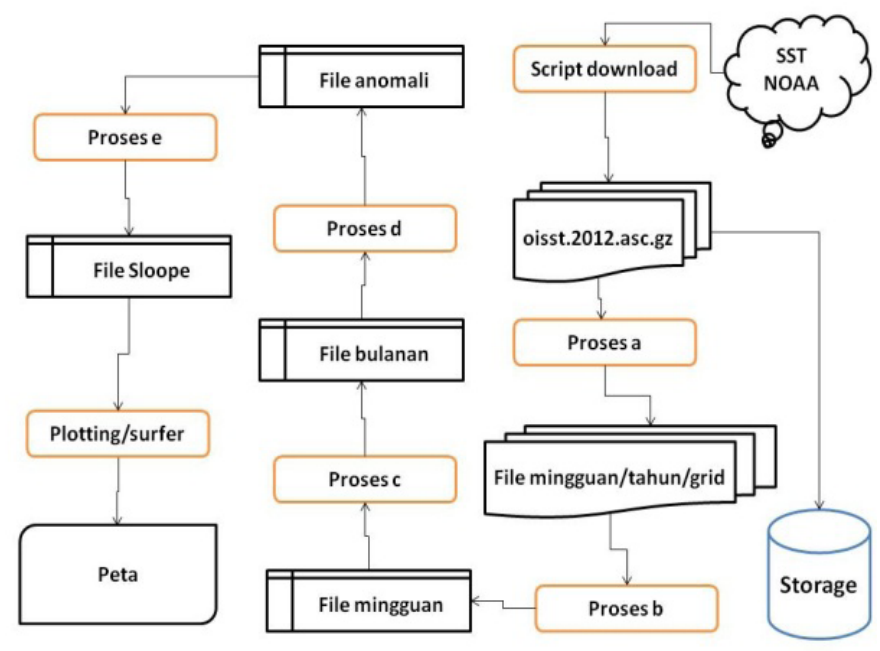

Gambar 2. Flow chart pengolahan data SPL mulai dari pengunduhan file sampai mencari nilai slope dan menampilkannya ke dalam peta spasial.

dapat dilakukan dengan lebih efisien dan efektif. Jumlah grid yang dianalisis adalah 61 buah grid bujur $\mathrm{x}$ 26 buah grid lintang (1.586 buah grid).

Sript pengunduhan file SPL (script download) digunakan untuk mengunduh secara otomatis dan melakukan updating data secara rutin setiap minggunya. Program Fortran telah dikembangkan dari Moin (2012) untuk membaca file SPL mingguan perairan Indonesia secara spasial setiap gridnya, secara temporal selama 32 tahun setiap minggu selama 53 minggu (proses a). Program Turbo Pascal untuk menggabungkan data SPL mingguan menjadi satu file untuk masing masing grid. Karena masingmasing grid dan tahun berupa file terpisah maka diperlukan program untuk menggabungkan file mingguan selama 32 tahun menjadi satu file untuk setiap grid-nya (proses b). Program Turbo Pascal untuk membaca file mingguan menjadi data bulanan (proses c). Setelah satu grid mempunyai satu file (mingguan) maka dibuat file bulanan dari data mingguan (rerata). Script pengunduhan SPL dari NOAA ditulis dengan c-shel di sistem operasi linux. Sebelum menjalankan script ini perlu ada aplikasi unduh otomatis bernama wget.

File SPL berupa satu file untuk setiap tahunnya sehingga program Fortran akan membuat sekitar 50.750 buah file (1.586 grid $\times 32$ tahun). Prosesnya adalah, pertama menggabungkan data SPL mingguan menjadi satu file. Setelah file mingguan dibuat, kemudian dibuat data bulanan dengan melakukan rerata bulanan untuk masing-masing grid selama 32 tahun. Setelah diperoleh data bulanan kemudian dibuat anomalinya dengan cara dikurangi terhadap nilai historisnya (proses d). Nilai historis dihitung dari rerata selama 32 tahun. Setelah diperoleh nilai anomali bulanan untuk setiap gridnya, kemudian dihitung nilai kemiringan (slope) untuk setiap grid (proses e). Perhitungan slope dilakukan dengan persamaan sebagai berikut :

$$
\text { Slope }=\frac{\sum(x-\bar{x})(y-\bar{y})}{\sum(x-\bar{x})^{2}}
$$

Hasil pemrosesan ditampilkan dengan perangkat lunak Golden Software SURFER versi 11, setelah merubah format nilai slope sesuai dengan format surfer. Pengolahan berikutnya dilakukan menggunakan perangkat Microsoft Excel untuk menyusun time series anomali SPL dan melihat tren atau kecenderungannya.

\section{Analisis Data}

Analisis dilakukan dengan dua cara yaitu analisis temporal dan analisis spasial. Analisis temporal untuk melihat tren dari anomali suhu permukaan laut rerata beberapa wilayah tertentu. Analisis spasial dilakukan pada nilai anomali suhu permukaan laut bulanan dan nilai slope-nya. Analisis spasial anomali suhu permukaan laut bulanan untuk melihat wilayah mana saja yang mempunyai nilai anomali positif maupun negatif. Sementara, analisis spasial dari nilai slope anomali suhu permukaan laut akan mendapatkan wilayah yang mengalami kenaikan suhu permukaan laut (slope positif) dan yang tidak.

\section{Analisis Temporal Anomali SPL}

Analisis temporal dilakukan di empat wilayah perairan di Indonesia dengan asumsi keempat wilayah tersebut memiliki karasteristik suhu permukaan laut yang mempengaruhi kondisi cuaca dan iklim di beberapa tempat di wilayah Indonesia. Keempat 
wilayah tersebut adalah : perairan Selatan Jawa, perairan Barat Sumatera, Laut Cina Selatan dan perairan Utara Papua seperti dalam Gambar 3.

Analisis temporal tersebut dilakukan terhadap empat rerata triwulan yaitu, September - Oktober November (SON), Desember - Januari - Februari (DJF), Maret - April - Mei (MAM) dan Juni - Juli Agustus (JJA). Hasil rerata keempat triwulan tersebut kemudian di plot secara time series dan dicari persamaan linear dari garis tren-nya (trendline). Persamaan linear dibuat untuk menentukan nilai koefisien regresi dari time series data suhu permukaan laut. Apabila nilai koefisien regresi tersebut adalah positif maka mengindikasikan adanya tren kenaikan suhu permukaan laut. Sebaliknya jika nilai koefisien regresi tersebut negatif maka mengindikasikan adanya tren penurunan nilai suhu permukaan laut. Semakin besar nilai koefisien regresi semakin kuat tren peningkatan /penurunan suhu permukaan laut.

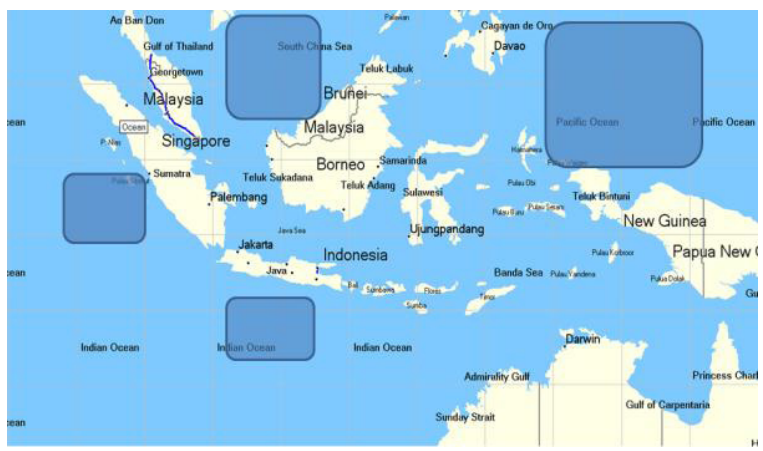

Gambar 3. Empat lokasi pengamatan temporal anomali suhu permukaan laut (daerah yang diarsir).

\section{HASIL DAN PEMBAHASAN}

\section{Perairan Selatan Jawa}

Perairan selatan Jawa dalam studi kasus ini adalah bagian timur Samudera Hindia dibatasi koordinat $15^{\circ} \mathrm{LS} \sim 10^{\circ} \mathrm{LU}$ dan $105^{\circ} \sim 120^{\circ} \mathrm{BT}$. Hasilnya disajikan pada Gambar 4. Hasil analisis daerah tersebut menunjukkan untuk bulan-bulan SON mempunyai nilai slope $=+0,0428$, DJF slope $=+0,0353$, MAM slope $=+0,0193$ dan JJA slope $=+0,0294$. Secara umum wilayah ini mengalami peningkatan SPL selama lebih dari 32 tahun terakhir. Pada musim basah (SON dan DJF) nilai peningkatan SPL relatif lebih besar dibandingkan pada musim kering (MMA dan JJA).

\section{Perairan Barat Sumatera}

Perairan barat Sumatera yang juga merupakan bagian Samudera Hindia dibatasi oleh koordinat Ekuator $\sim 08^{\circ} \mathrm{LS}$ dan $90^{\circ} \sim 100^{\circ} \mathrm{BT}$. Hasilnya disajikan pada Gambar 5. Hasil analisis daerah tersebut menunjukkan untuk bulan-bulan SON mempunyai nilai slope $=+0,0736$, DJF dengan slope $=+0,0321$, MAM dengan slope $=+0,0406$ dan JJA dengan slope $=+0,0058$. Secara umum, wilayah ini mengalami peningkatan SPL selama lebih dari 32 tahun terakhir.

\section{Laut Cina Selatan}

Perairan Laut Cina Selatan dibatasi oleh
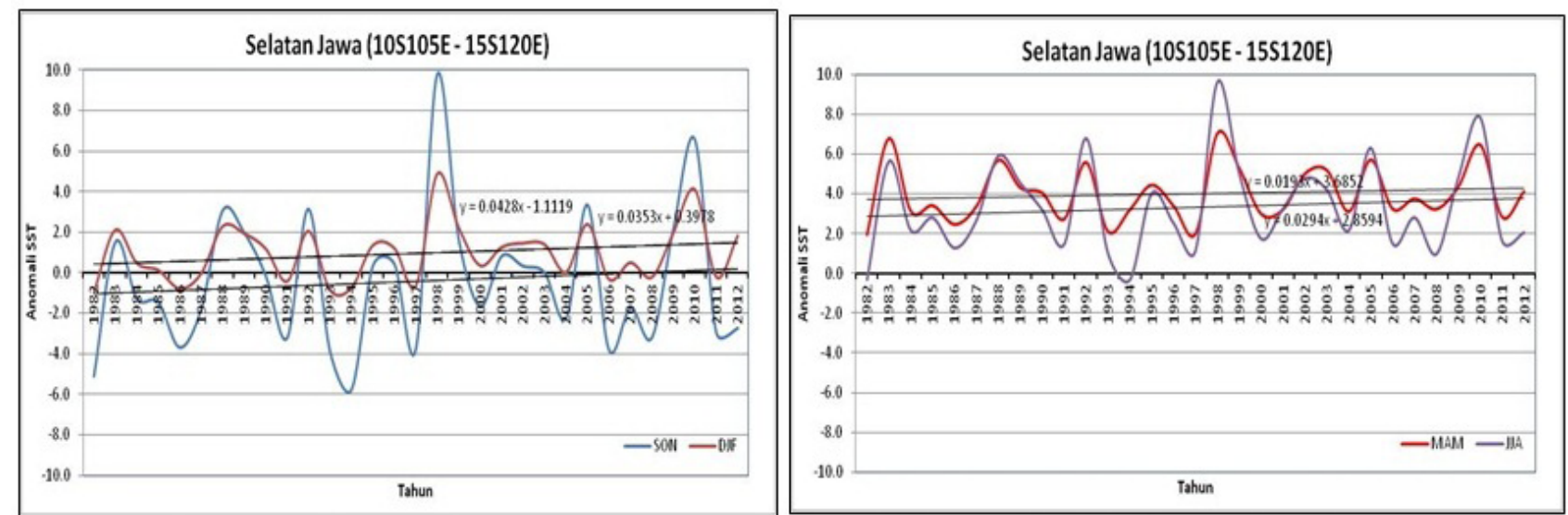

Gambar 4. Analisis slope untuk perairan selatan Jawa pada bulan-bulan SON, DJF, MAM dan JJA. 

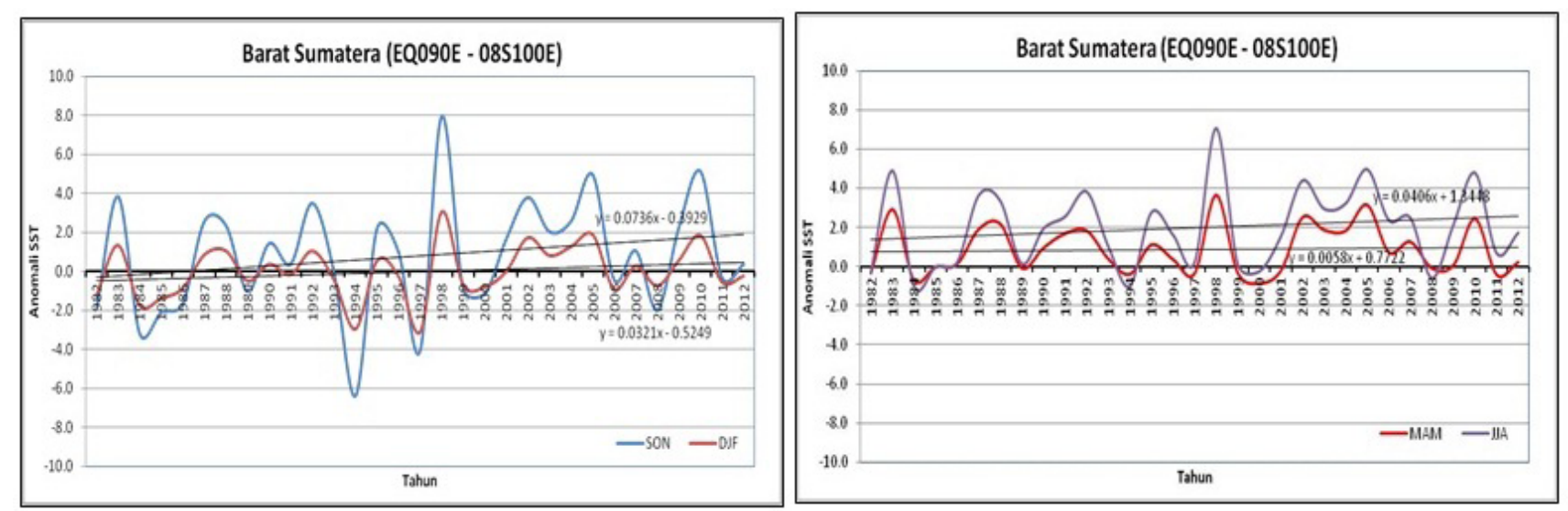

Gambar 5. Analisis slope untuk perairan selatan Jawa pada bulan-bulan SON, DJF, MAM dan JJA.

koordinat $15^{\circ} \mathrm{LS} \sim 10^{\circ} \mathrm{LU}$ dan $105^{\circ} \sim 120^{\circ} \mathrm{BT}$. Hasilnya disajikan pada Gambar 6. Hasil analisis untuk wilayah Laut Cina Selatan menunjukkan untuk bulan-bulan SON mempunyai nilai slope $=+0,0283$, DJF dengan slope $=+0,0143$, MAM dengan slope $=+0,0109$ dan JJA dengan slope $=+0,001$. Secara umum wilayah ini mengalami peningkatan SPL yang lebih rendah dibandingkan dua wilayah sebelumnya. Pada musim basah (SON dan DJF) nilai peningkatan SPL relatif lebih besar dibandingkan pada musim kering (MMA dan JJA) yang hampir tidak mengalami peningkatan.

\section{Laut Utara Papua}

Perairan utara Papua adalah bagian wilayah Samudera Pasifik Barat dibatasi oleh koordinat $0^{\circ}$ (ekuator) $\sim 13^{\circ} \mathrm{LU}$ dan $130^{\circ} \sim 150^{\circ} \mathrm{BT}$. Wilayah ini termasuk Samudera Pasifik sebelah barat yang letaknya berdekatan dengan daerah maritim kontinen. Hasil analisis seperti terlihat pada Gambar 7 untuk wilayah ini menunjukkan bulan-bulan SON mempunyai nilai slope $=+0,1788$, DJF dengan slope $=+0,0957$, MAM dengan slope $=+0,1305$ dan JJA dengan slope $=+0,0891$. Secara umum wilayah ini mengalami peningkatan SPL yang paling besar dibandingkan dengan wilayah lain yang dijadikan studi kasus.

Nilai slope di wilayah ini adalah nilai slope yang tertinggi dibandingkan dengan wilayah lain. Dengan kondisi bahwa perairan sebelah Utara Papua adalah bagian lautan luas (samudera) sehingga mempunyai jumlah kapasitas panas yang lebih besar, maka kenaikan nilai slope ini diperkirakan akan mempengaruhi kondisi iklim di wilayah Indonesia terutama bagian timur. Nilai
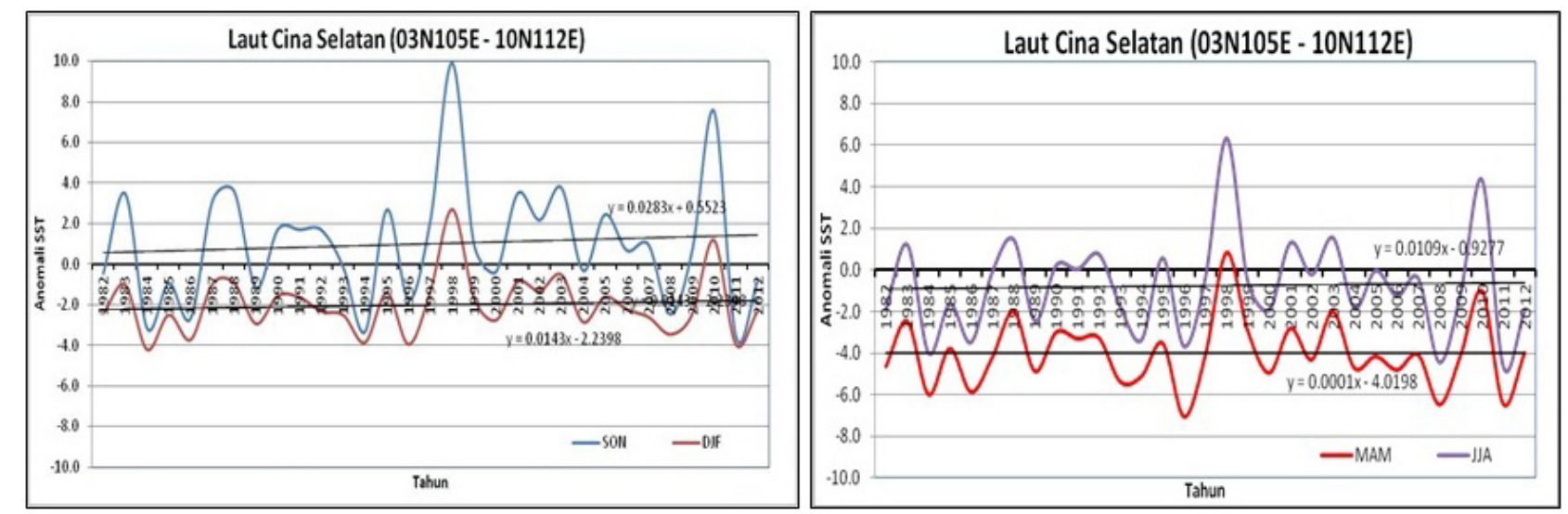

Gambar 6. Analisis slope untuk perairan Laut Cina Selatan pada bulan-bulan SON, DJF, MAM dan JJA.

Tabel 2.

Nilai slope untuk masing-masing perairan selama empat triwulan

\begin{tabular}{lllll}
\hline Wilayah & SON & DJF & MAM & JJA \\
\hline Selatan Jawa & $+0,0428$ & $+0,0353$ & $+0,0193$ & $+0,0294$ \\
Barat Sumatera & $+0,0736$ & $+0,0321$ & $+0,0406$ & $+0,0058$ \\
Laut Cina Selatan+0,0283 & $+0,0143$ & $+0,0109$ & $+0,0001$ \\
Utara Papua $+0,1788$ & $+0,0957$ & $+0,1305$ & $+0,0891$ \\
\hline
\end{tabular}



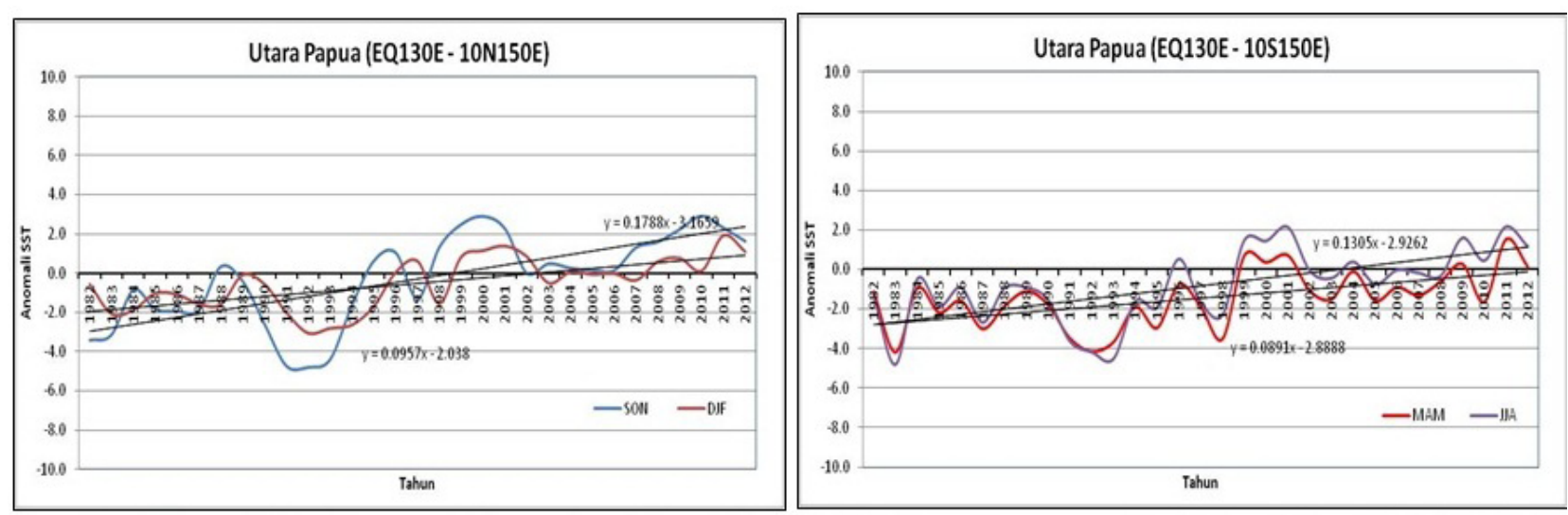

Gambar 7. Analisis slope untuk perairan Laut di sebelah Utara Papua pada bulan-bulan SON, DJF, MAM dan JJA.

slope masing masing wilayah untuk keempat triwulan disajikan dalam Tabel 2. Dari Tabel 2 terlihat bahwa semua daerah studi kasus mempunyai nilai slope yang positif dengan nilai yang bervariasi.

Hal ini memberi pengertian bahwa selama lebih 32 tahun telah terjadi peningkatan SPL di wilayah Indonesia yang bervariasi. Kenaikan suhu permukaan laut yang paling besar terjadi di perairan Pasifik Barat di sebelah utara Papua.

\section{Analisis Spasial Anomali SPL}

Setelah proses rerata bulanan, dilakukan nilai SPL dibuat historis bulanan selama 32 tahun pengamatan untuk setiap grid-nya. Nilai historis ini digunakan untuk membuat anomali SPL bulanan masing-masing gridnya dengan cara mengurangkan nilai aktual SPL terhadap nilai historisnya. Perhitungan anomali SPL setiap grid-nya dilakukan setiap minggu mulai minggu pertama Januari sampai dengan minggu ke-4 Desember. Analisis untuk tahun 2012 dilakukan setiap minggu dengan membuat peta anomali SPL dari minggu pertama Januari 2012 sampai minggu ke empat Desember 2012.

Gambar 8. adalah contoh peta anomali SPL wilayah Indonesia pada minggu pertama Januari 2012 dan minggu kedua Januari 2012. Warna merah menunjukkan nilai anomali positif yang artinya suhu permukaan laut saat itu lebih tinggi (panas) dibandingkan dengan suhu reratanya (historis), sedangkan warna biru menunjukkan sebaliknya (anomali negatif).

Secara umum dapat dilihat bahwa anomali suhu permukaan laut (SPL) di wilayah Indonesia terbagi menjadi anomali positif dan anomali negatif yang terpisah di belahan bumi bagian selatan dan belahan bumi bagian utara. Pada musim hujan maupun musim kering nampak terjadi perbedaan anomali SPL yang sangat signifikan antara wilayah bagian utara dengan wilayah bagian selatan. Pada Januari (Gambar 8) yang merupakan bulan basah, anomali SPL perairan selatan mulai dari selatan Pulau Sumatera, selatan Pulau Jawa sampai Kepulauan Nusa Tenggara Timur bernilai positif yang cukup signifikan $\left(+2,5^{\circ} \mathrm{C}\right)$. Sedangkan, di wilayah utara, terutama di Laut Cina Selatan, anomali SPL bernilai negatif secara signifikan $\left(-3,0^{\circ} \mathrm{C}\right)$. Hal ini menyebabkan wilayah Indonesia terutama di Pulau Sumatera dan Pulau Jawa banyak mendapatkan supplay awan sehingga banyak terjadi hujan.

Pada Juli (Gambar 9) yang merupakan musim kering, anomali SPL di perairan selatan Jawa ke timur sampai Nusa Tenggara Timur dan selatan Papua bernilai negatif yang cukup signifikan $\left(-6.0^{\circ} \mathrm{C}\right)$. Sedangkan di wilayah utara, nilai anomali SPL bertanda positif $\left(+2 \cdot 5^{\circ} \mathrm{C}\right)$. Hal ini menyebabkan wilayah Indonesia bagian Jawa, Bali, Nusa Tenggara Barat sampai Nusa Tenggara Timur sangat kering sehingga sulit terjadi hujan. Pada musim-musim transisi seperti Maret dan April, perbedaan antara anomali positif dengan anomali negatif tidak begitu besar $\left(+2,0^{\circ} \mathrm{C}\right.$ sampai $-1,5^{\circ} \mathrm{C}$ ) sehingga pada bulan-bulan tersebut masih ada peluang pertumbuhan awan di beberapa wilayah di Indonesia.

\section{Analisis Spasial Slope SPL}

Setelah analisis temporal suhu permukaan laut dilakukan dengan menghitung nilai slope dari set data SPL untuk masing-masing grid-nya, maka dibuat peta spasial nilai slope dibuat sehingga diketahui nilai sebarannya. Analisis spasial slope SPL dilakukan untuk melihat daerah-daerah yang mempunyai tren peningkatan SPL dan daerah-daerah yang mempunyai tren penurunan. Pembuatan peta spasial nilai slope dilakukan untuk September, Oktober dan November (SON), Desember, Januari dan Februari (DJF), Maret, April dan Mei (MAM) dan Juni, Juli dan Agustus (JJA). Keempat peta spasial nilai slope masing-masing 


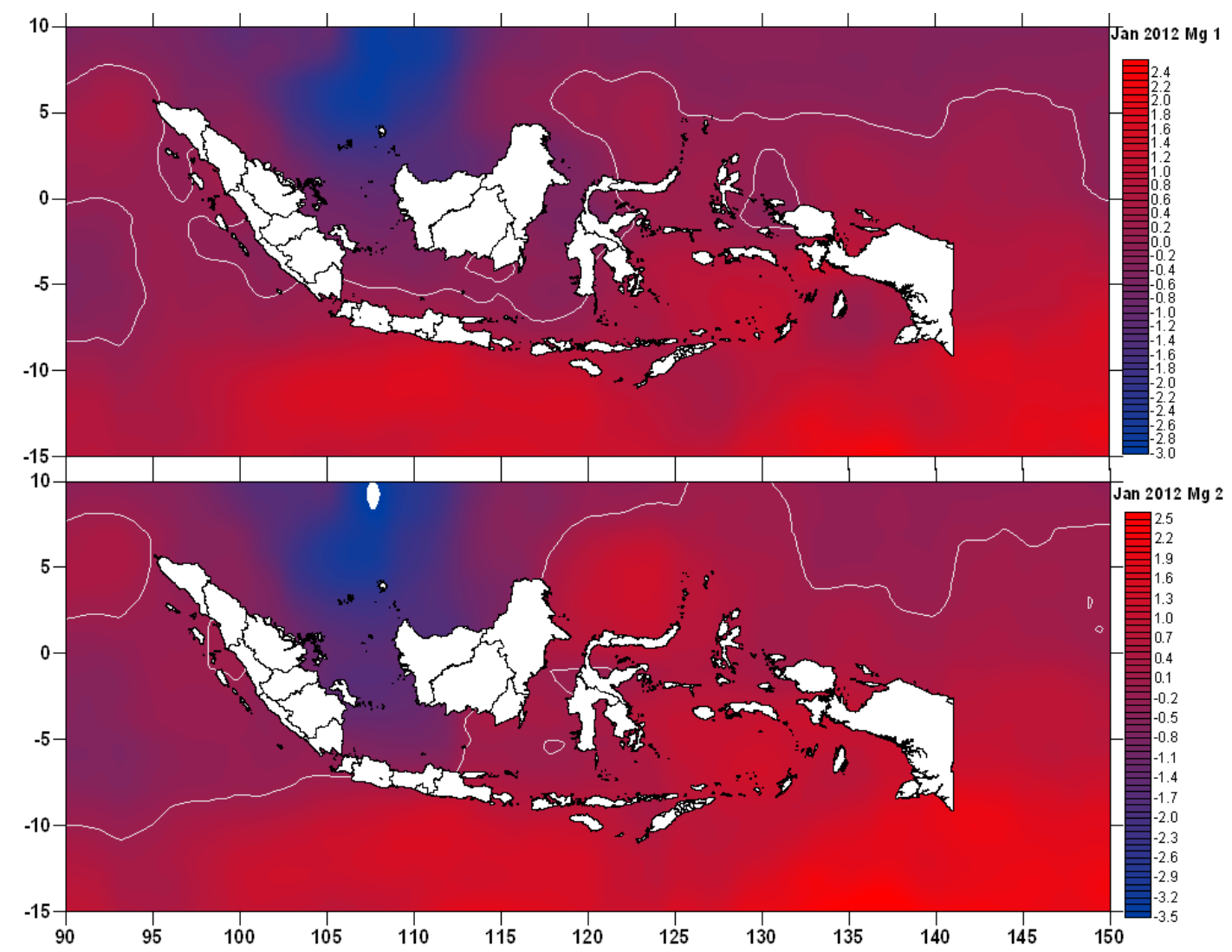

Gambar 8. Peta Anomali SPL Bulan Januari 2012 (minggu ke-1 (atas) dan minggu ke-2 (bawah)).

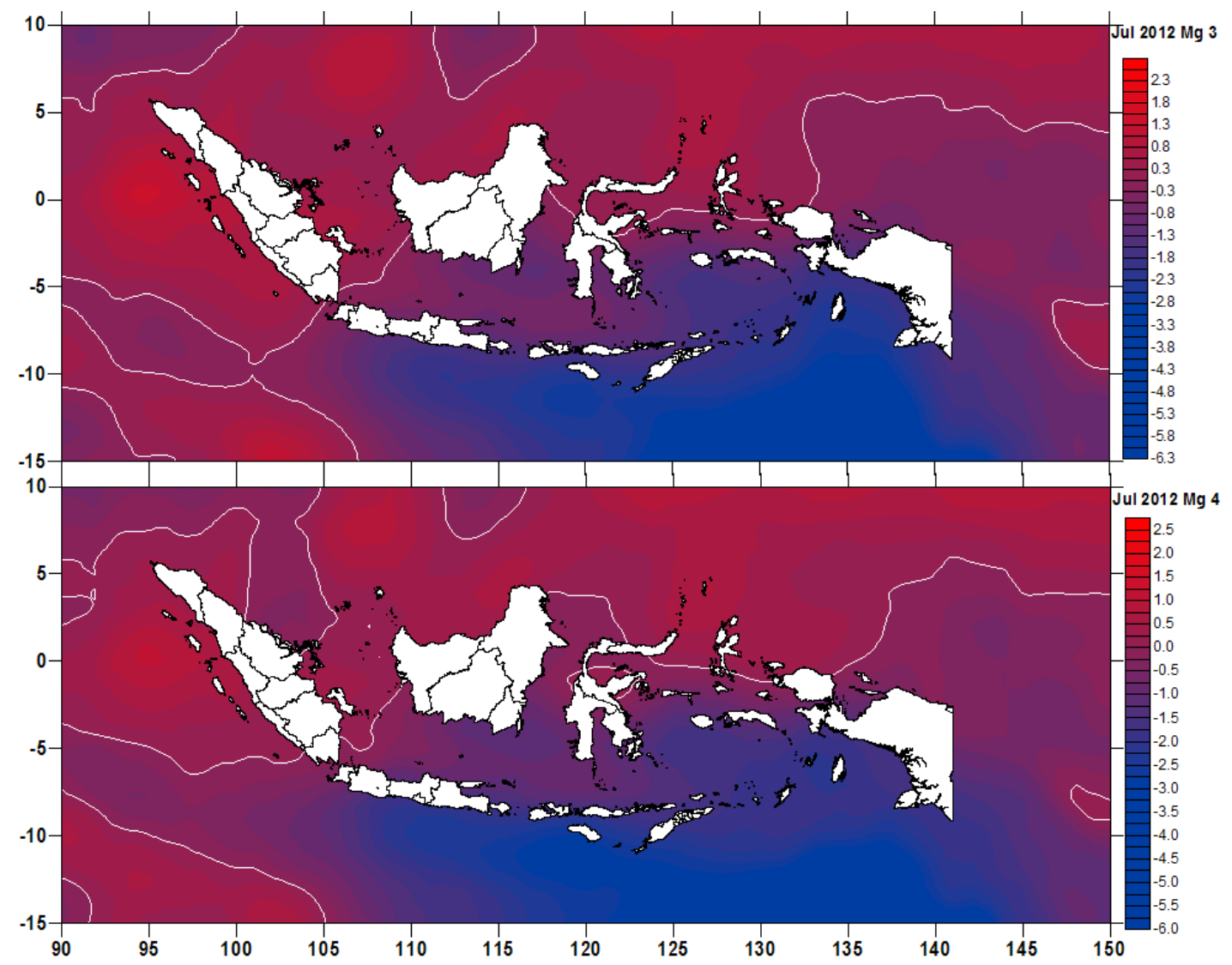

Gambar 9. Peta Anomali SPL Bulan Juli 2012 (minggu ke-3 (atas) dan minggu ke-4 (bawah)). 

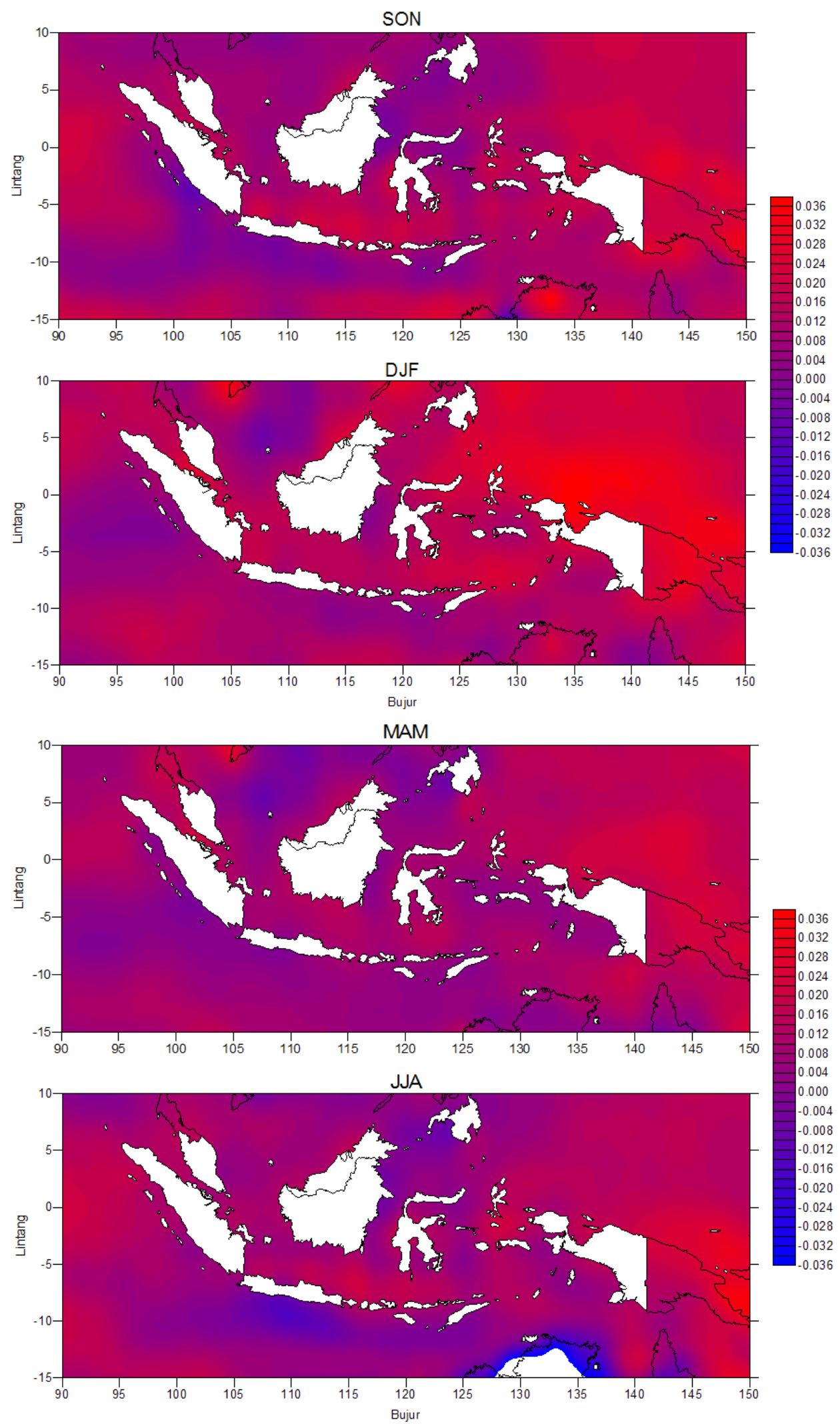

Gambar 10. Citra analisis slope nilai SPL perairan Indonesia bulan Maret-April-Mei (MAM) dan Juni-JuliAgustus (JJA), (atas) dan untuk Bulan September-Oktober-November (SON) dan DesemberJanuari-Februari (DJF) (bawah), Cat Warna merah adalah slope positif sebaliknya warna biru adalah slope negatif. 
triwulan dapat dilihat pada Gambar 10.

Dari Gambar 10, terlihat adanya variasi spasial nilai slope positif dan negatif. Secara umum, wilayah yang mengalami peningkatan SPL dengan nilai slope positif adalah perairan sebelah utara Papua, Samudera Hindia sebelah Barat Sumatera sebagian Laut Jawa, dan di sekitar Laut Banda. Sedangkan di Laut Cina Selatan, perairan selatan Jawa relatif konstan dan cenderung mengalami penurunan SPL meskipun sangat kecil. Dilihat dari nilai slope-nya perairan Samudera Pasifik di utara Papua merupakan wilayah yang tertinggi dibandingkan dengan wilayah lain.

Pengamatan yang secara spasial menunjukkan daerah-daerah dimana terjadi penurunan SPL (nilai slope negatif) meskipun sangat kecil, terutama di wilayah Laut Cina Selatan dan perairan Selatan Jawa. Hal ini tidak terlihat secara nyata pada analisis temporal anomali SPL karena dalam analisis tersebut dilakukan pererataan wilayah dari daerah yang dianalisis.

\section{KESIMPULAN} berikut :

Dari hasil penelitian ini dapat disimpulkan sebagai

1. Hasil analisis menunjukkan nilai slope untuk keempat wilayah adalah positif. Nilai slope di wilayah Utara Papua merupakan yang tertinggi dibandingkan dengan wilayah lain.

2. Hasil analisis secara spasial dari nilai slope menunjukkan bahwa selama 32 tahun telah terjadi peningkatan suhu permukaan laut di wilayah Indonesia yang bervariasi.

3. Secara umum dapat dilihat bahwa anomali SPL di wilayah Indonesia terbagi menjadi anomali positif dan negatif yang terpisah di belahan bumi bagian selatan dan belahan bumi bagian utara.

\section{PERSANTUNAN}

Ucapan terimakasih disampaikan kepada Unit Pelaksana Teknis Hujan Buatan (UPTHB) Badan Pengkajian dan Penerapan Teknologi (BPPT), juga kepada rekan peneliti UPTHB atas kerjasamanya dalam melakukan proses data yang sangat besar di dalam server.

\section{DAFTAR PUSTAKA}

Aldrian E \& Susanto R. D. (2003). Identifikasi tentang tiga wilayah hujan yang dominan di Indonesia dan hubungannya dengan suhu permukaan laut, Jurnal Internasional tentang iklim, Vol. 23, No 12, pp.1435-1452, doi 10.1002/joc.950

Awaluddin, M.Y., J. Kaempf \& Ewenz, C. (2010).
Perbedaan suhu permukaan laut di lautan Indonesia: hasil Awal /Pendahuluan. AMOS 17Th Konferensi Presentasi Poster. ANU Canberra.

Awaluddin, M.Y. (2011). Karakteristik Suhu Permukaan Laut dan Hujan di Indonesia, (http://blogs .unpad. ac.id/ myawaludin/files/2011/08/8.-Muhamm adYusuf-A-UNPAD-2011.pdf), diakses Januari 2015

Cressman, G. P. (1959). An operational objective analysis system. Mon. Wea. Rev., 87, 367-374

Emiyati, Setiawan, K. T., Manopo, A. KS., Budhiman, S \& Hasyim, B. (2014) Analisis Multitemporal Sebaran Suhu Permukaan Laut di Perairan Lombok Menggunakan Data Penginderaan Jauh Modis, Seminar Nasional Penginderaan Jauh LAPAN.

Febriani, F.R., Seni, H.J.T. \& Wandayantolis. (2014). Analisis Spasial Pengaruh Dinamika Suhu Muka Laut Terhadap Distribusi Curah Hujan di Sulawesi Utara, Jurnal MIPA Unsrat, (http://ejournal.unsrat. ac.id/index.php/jmuo), diakses Januari 2015.

Masters, J. The Landmark 2007 IPCC Report on Climate Change, (http://www.wunderground.com/ resources/climate/ipcc2007.asp?MR=1), diakses 12 November 2012.

Moin, P. Mathematical and Computational Methods for Engineer, Fortran 77 Tutorial, Course outline, (http://www.standford.edu/class/me200c/ tutorial_77/), diakses 23 Novemver 2012.

National Centers for Environmental Prediction, National Weather Service, NOAA, NCEP Version 2.0 OI Global SST and NCDC Version 3.0 Extended Reconstructed SST Analyses. (http://rda.ucar. edu/datasets/ds277.0/), diakses 7 Desember 2012.

Reylods, R. W. (1988). A Real-time Global Sea Surface Temperature Analysis, J. Climate, 1, 75-86.

Reynolds, R.W., N.A. Rayner, T.M. Smith, D.C. Stokes, \& Wang, W. (2002). An Improved In Situ and Satellite SST Analysis for Climate. J. Climate, 11, 3320-3323.

Reynolds, R.W. \& D.C. Marsico. (1993). An Improved Real-time Global Sea Surface Temperature Analysis, J. Climate, 6, 114-119.

Smith, T.M., R.W. Reynolds, Thomas C. Peterson, \& Jay Lawrimore. (2007). Improvements to NOAA's Historical Merged Land-Ocean Surface Temperature Analysis (1880-2006). J. Climate, 
21(10), 2283-2296.

Surfer 11 Powerful Contouring, Gridding, and 3D

Surface Mapping Software for Scientists and Engineers. (2013). (http://www.goldensoftware. com/products/surfer), diakses Januari 2013.

Sudarman. (2010). Meminimalkan Daya Dukung Sampah Terhadap Pemanasan Global Profesional, Vol.8, No.1, Mei 2010, ISSN 16933745

Syaifullah, D. (2010). Analisis Suhu permukaan laut Selatan Jawa dan Pengaruhnya terhadap Curah Hujan DAS Citarum. Jurnal Sains \& Teknologi Modifikasi Cuaca (JSTMC) Vol. 11 No. 2 Desember 2010 